\title{
Industrial Relations as a Source of Solidarity in Times of Welfare State Retrenchment
}

\section{CHRISTINE TRAMPUSCH}

Department of Political Science, University of Berne, Lerchenweg 36, CH-3000 Berne 9, Switzerland

email: trampusch@ipw.unibe.ch

\begin{abstract}
Within the literature on retrenchment policies, the 'solidarity-decline thesis' is discussed. It is argued that current welfare state restructuring leads to a decrease in the actual social cohesion of society because redistributive public benefits are cut. The article addresses this thesis by presenting empirical evidence on social security based on collective bargaining. In Denmark, France, Germany and the Netherlands, collective agreements are increasingly used to regulate and finance social benefits. These collectively negotiated benefits may compensate to a certain degree for solidarity losses caused by retrenchment policies. The article reviews concepts of solidarity used in the literature and develops a two-dimensional scheme of four different concepts. The conclusion for comparative welfare state research is twofold. First, when viewing policies of welfare state retrenchment, the research should systematically include industrial relations in its frame of reference. Second, further studies should analyse the politics as well as the outcomes of collectively negotiated benefits more systematically. Under certain conditions, which are worth specifying, collective bargaining may lead to complex public-private mixes that shift welfare states in other directions than outright market liberalisation, not only in factual but also in normative terms.
\end{abstract}

\section{Introduction}

In comparative welfare state research, the words 'restructuring' and 'retrenchment' are sometimes used as if they mean the same thing. Welfare state restructuring is often analysed mainly as retrenchment (Green-Pedersen and Haverland, 2002: 43), and, within the literature on retrenchment policies, studies which conceptualise retrenchment as broader than market liberalisation are rare (Hacker, 2002; Hyde et al., 2003; van der Veen, 2005). When political scientists and sociologists analyse welfare state retrenchment, they normally treat retrenchment policies as moves to more privately organised welfare policies in which the market mechanism will gain importance (Clark, 2003; Gilbert and van Voorhis, 2003: 3; Gilbert, 2004, 2005). On the one hand, this leads researchers to argue that, due to the decision in favour of the free-market model, trade unions and employers' organisations lose competencies in the provision of welfare (Molina and Rhodes, 2002: 306 ). On the other hand, it is suggested that the social cohesion of society is 
reduced because redistributive public benefits are cut and replaced by dispersed competition (cf. van Oorschot, 1998; Bergmark et al., 2000; Greve, 2004). In this context, the literature discusses the 'solidarity-decline thesis' (Ullrich, 2002: 123), the argument that the principle of social solidarity - that is the 'willingness to make sacrifices for the wellbeing of the other members of a group' (Beckert et al., 2004: 9; italics added) - loses importance. Van Oorschot argues that in many European countries, welfare state restructuring reduces the 'access to universal protection schemes' and replaces 'solidaristic social insurance programmes' with 'individualistic, market-led private insurance' (1998: 183-4).

The problem with these assessments on the effects of welfare state restructuring is that they do not take account of studies pointing out the fact that collective agreements between trade unions and employers on social benefits have recently been expanded (for example, van der Veen, 1998, 2005: 8, 50; Hyde et al., 2003; Trampusch, 2005, 2006, 2007; Ebbinghaus, 2006). This literature is supported by studies of the European Industrial Relations Observatory (EIRO), which reveal that in various continental and Scandinavian welfare states collective agreements are increasingly being used to regulate and finance welfare issues (EIRO, 1998, 2001, 2004a, 2004b). ${ }^{1}$ The EIRO studies show that the self-regulative role of the collective bargaining partners has recently been strengthened, especially in Denmark, France, Germany and the Netherlands. This has happened mainly in the domains of occupational pensions, early retirement and further training (EIRO, 1998, 2001, 2004a, 2004b). ${ }^{2}$

Collectively negotiated benefits represent a theoretical problem for the literature on retrenchment policies as, in a system of welfare provided by industrial agreements, it is not markets that decide on individual wellbeing, but actors that are collective in their nature. Through collectively negotiated benefits, trade unions and employers' organisations may be able to compensate solidarity losses caused by retrenchment of public benefits by solidarity gains that result from benefits negotiated collectively through the agreements between unions and employers. Hence, if we include industrial agreements on welfare benefits in our analysis of retrenchment policies, this probably provides less straightforward and more complex answers to the question of how retrenchment policies affect social solidarity. Against this background, the article suggests some analytical considerations that allow us to include collectively negotiated benefits in the discussion of the solidarity-decline thesis.

The article is divided into four sections. In the first section, I argue that welfare state restructuring should be re-interpreted by focusing on the emergence of social security arrangements created on the basis of collective agreements between unions and employers' associations. In the second section, I define the concept of social solidarity and discuss the type of solidarity associated with collective agreements on social security. In the third section, I describe collectively negotiated benefits in Denmark, France, Germany and the Netherlands, and 
assess the capacity of these collective agreements to promote social solidarity. The fourth section summarises my findings.

\section{Welfare state restructuring and collective agreements}

Despite the diversity of conceptual and theoretical claims found in studies of current welfare state restructuring, one basic argument can be found in the literature: in analysing welfare state restructuring, most studies focus on retrenchment policies, hence on cuts in public welfare programmes, which result in residual welfare states because the cuts undermine the redistributive aims of social policy (about which, see Green-Pedersen and Haverland, 2002: 43). Since Pierson's Dismantling the Welfare State? (1994) the study of retrenchment has become the main focus of comparative welfare state research in general and of the literature on welfare state restructuring in particular. Welfare state restructuring is often equated with retrenchment, hence with a move to more market-oriented schemes of social security.

Pierson concludes that retrenchment describes 'policy changes that either cut social expenditure, restructure welfare state programmes to conform more closely to the residual welfare state model, or alter the political environment in ways that enhance the probability of such outcomes in the future' (1994: 17). Following Titmuss' distinction between institutional and residual welfare states, Pierson conceives the residual welfare state as 'more reluctant to interfere with market mechanisms'. 'Residual welfare states', he claims, 'reject comprehensive services, and prefer state subsidisation of private services to public provision' (Pierson, 1994: 15).

As to the growing role of the private sector in the provision and financing of welfare in times of retrenchment, the literature mainly focuses on private benefits delivered by the market. It is important, however, to note that the move of welfare states towards the private provision of welfare can embrace different kinds of development. It could mean that states place greater responsibilities on individuals to secure their own welfare by means of private insurance schemes. But the private provision of welfare could also be organised by actors that are collective by nature, such as families, non-profit organisations, trade unions or employers' associations.

Despite this diversity in private alternatives to public welfare, most studies are premised on Pierson's (1998: 556) claim that retrenchment reforms lie on a continuum from the status quo to full liberal retrenchment, that is to a full market-oriented system of provision. It is often argued that even Scandinavian and continental welfare states are gripped by measures of privatisation (EspingAndersen, 1996: 335; van der Veen and Trommel, 1999; Alber, 2003: 63; Lindbom and Rothstein, 2004: 7). The literature claims that markets increasingly determine individual wellbeing in dismantled welfare states (Shalev, 1996: 1). 
In his recent analysis of the 'Transformation of the Welfare State', Gilbert characterises the contemporary transformation of welfare states as the 'triumph of capitalism' (2004: 5). Summarising the core assumptions on which most retrenchment studies are based, Hyde et al. (2003: 189-90) argue that the literature conceptualises welfare state restructuring mainly as a move to the free-market model.

As a lot of these studies conclude that there is a general trend toward shifting the responsibility for the provision of welfare from the state to private actors and organisations (for example, Gilbert, 2004, 2005; unlike van der Veen, 2005: 8 ), the research often argues that the principles, the values and the conceptions of social order underlying social security systems are changing (cf. Clasen and van Oorschot, 2002; Leitner and Lessenich, 2003; Cox, 2004). It is in this context that the 'solidarity-decline thesis' is discussed (Ullrich, 2002: 123). This thesis of solidarity losses caused by retrenchment is approached in two ways. On the one hand, the literature refers to factual solidarity; on the other, to normative and affective connotations of solidarity. Whereas the first group argues that current retrenchment policies lead to a decrease in actual social cohesion because redistributive public benefits are cut (cf. Oorschot, 1998; Bergmark et al., 2000; Greve, 2004), the second group maintains that retrenchment affects individual motivations and sentiments and, in general, produces a loss of popular support for redistributive policies (cf. Bergmark et al., 2000; Arts and Gelissen, 2001; TaylorGooby, 2001; Ullrich, 2002). ${ }^{3}$ Following this view of retrenchment as market liberalisation, the trade unions' and employers' roles in social policy seem to be of declining importance, especially in cases where governments have successfully cut public benefits (about which, see also Béland, 2001).

Do retrenchment policies really produce a general tendency to undermine the roles of trade unions and employers in the management of social policy? Do retrenchment policies ultimately result in solidarity losses? If we presume (with de Swaan, 1988: 148) that collective agreements may offer some 'form of authentic solidarity and collective care', the answer may not be so straightforward, because industrial agreements on welfare benefits may compensate to a certain degree for the decline in solidarity produced by welfare state retrenchment. Hence, my response to the question of solidarity losses by retrenchment is that whether we link retrenchment to such a mechanism or not depends on the perspective.

If we take a narrow perspective - that is, if we conclude, like Pierson (1994: 15) does, that retrenchment will lead to more residual welfare states, in which the market mechanism will gain importance - then our answer will be in the affirmative. Analysing welfare state restructuring as cuts in public benefits through which governments intend to move to a system where markets - and not collective actors - increasingly decide on individual wellbeing leads to a narrow perspective of welfare state restructuring. The definition of retrenchment as market liberalisation implies that we conceive the provision of collectively 
organised welfare mainly in terms of schemes that are legally institutionalised by the state through public transfers and insurance schemes; that is, through nationwide, state-controlled, compulsory institutions of social security. If these public benefits are cut and the provision of welfare by the state is replaced by welfare provision by the market mechanism, the role of the social partners in the management of welfare is necessarily weakened and solidarity declines without any compensation.

However, if we take a wider perspective and assume that welfare state restructuring can embrace different kinds of development and that retrenchment could also mean that governments intend to organise the private provision of welfare by actors that are collective in nature - such as families, non-profit organisations, trade unions and employers' organisations - our answer to the question may be in either the affirmative or the negative (about which, see also Hyde et al., 2003; van der Veen, 2005: 50). Allowing that restructuring may go hand in hand with measures through which governments intend to delegate the financing and provision of welfare to other collectivities leads to a wider perspective. Cuts in public benefits that are provided through nationwide, statecontrolled, compulsory institutions of social security may be accompanied by the expansion of benefits provided by employers and trade unions through collective agreements.

From this perspective, it follows that the study of welfare state restructuring requires not only considerations about the change and restructuring of public schemes, but also claims about the emergence (viewed historically: re-emergence) of sub-national collective schemes of welfare, such as social security through industrial agreements. We should also include the behaviour of trade unions and employers' associations in the industrial arena. If we include collectively negotiated social welfare schemes in our studies on welfare state retrenchment, we may conclude that the position of collective bargaining systems as intermediary institutions between individuals (employees and managers) and their embeddedness in legal provisions by the state may allow governments and social partners to restructure welfare states in other directions than outright market liberalisation. In what follows, I argue that collective agreements on welfare benefits may additionally compensate to a certain degree for the solidarity decline that is caused by cuts in state social policy.

\section{Solidarity and solidaristic effects of collective agreements}

How can we analyse more precisely the degree of solidarity collectively negotiated agreements may provide? Before we begin to assess such effects, we should first clarify the concept of social solidarity by reviewing how welfare state research uses this concept; second, we need to highlight the capacity of collective agreements to provide social solidarity. 
'Solidarity' is a frequently used concept in welfare state research. Very generally, social solidarity may be defined as the 'willingness to make sacrifices for the wellbeing of the other members of a group' (Beckert et al., 2004: 9). Hence, the term 'solidarity' is linked to such non-market exchange relations, which, unlike reciprocity, may be one-sided (Leitner and Lessenich, 2003: 329). ${ }^{4}$

Although solidarity is one of the sociological key concepts - theoretical considerations of solidarity go back to Emil Durkheim and Max Weber and although there have been several recent attempts to define the term unambiguously (cf. Hechter, 1987; Bayertz, 1999; Lindenberg, 2002; Berger, 2005), welfare state research uses the term of solidarity not only very differently but also at times very vaguely. With Cox we can reason that the literature uses both a wide and a narrow conception of solidarity. Whereas authors using the wide conception link solidarity with the creation of 'programmes that break down class divisions or regional disparities' and argue that the 'maximum scope' of this kind of solidarity is universalism (Cox, 2004: 209), narrow conceptions of solidarity 'focus on the degree to which programs achieve redistributive ends, because redistribution demonstrates a commitment to the least well-off in a society' (Cox, 2004: 209-10). From Goodin et al. (1999: 37-55), we can conclude that the diversity in the way the concept is used in the literature may also result from the existence of different types of welfare state regimes (liberal, social democratic, corporatist welfare regime), which go hand in hand with distinctive sets of fundamental values, benefit structures and welfare outcomes (about which, see also Arts and Gelissen, 2001). Besides diversity in the way the concept is defined, much of the literature connects the attainment of solidarity mainly with the provision of public welfare schemes, ignoring and undervaluing the importance of other collectivities such as the family (about which, see Ostner, 2004) and collective agreements as source of solidarity. This contradicts the rich tradition of socio-political thought in welfare state research, which often discusses social security with reference to non-state actors and collectivities (cf. Titmuss, 1976 [1958]; de Swaan, 1988).

In order to provide a short overview of how the concept of solidarity is used in welfare state studies, I suggest the scheme shown in Table 1.

TABLE 1. Different dimensions of the concept 'solidarity'.

\begin{tabular}{|c|c|c|}
\hline & $\begin{array}{l}\text { Normative or affective } \\
\text { connotation }\end{array}$ & Factual conception \\
\hline Actors' dimension & $\begin{array}{l}\text { Solidarity as individual } \\
\text { motivation }\end{array}$ & $\begin{array}{l}\text { Solidarity as individual } \\
\text { action }\end{array}$ \\
\hline $\begin{array}{l}\text { Structural dimension } \\
\text { (institutionalised } \\
\text { dimension) }\end{array}$ & $\begin{array}{l}\text { Solidarity as moral } \\
\text { principle underlying } \\
\text { welfare schemes }\end{array}$ & $\begin{array}{l}\text { Solidarity as } \\
\text { institutionalised } \\
\text { arrangement }\end{array}$ \\
\hline
\end{tabular}


The scheme shows four ways of analysing solidarity. It is based on two dimensions. The first dimension differentiates between solidarity as normative or affective connotation and solidarity as factual conception. This differentiation was suggested by Hechter (1987). ${ }^{5}$ He defines solidarity as a function of the extensiveness of a group's obligations and the degree to which individual members actually comply with these (Hechter, 1987: 18). The second dimension distinguishes between whether solidarity is analysed at the individual level - as Hechter (1987) also suggests - or whether solidarity is viewed as a structural (institutionalised) phenomenon, a differentiation which Berger (2005: 14-15) has pointed out in his review of conceptions of social solidarity.

Referring to the actors' dimension, we can use the distinction proposed by Hechter (1987), and, hence, distinguish between solidarity as individual motivation and solidarity as individual action. Transferring Hechter's notion of solidarity to the structural (institutionalised) dimension, solidarity as a moral principle underlying welfare schemes has to be distinguished from a conception of solidarity as an institutionalised arrangement. This fourth conception comprises not only the sub-dimensions of welfare institutions that influence the degree of solidarity, such as entitlements, level of benefits or financing mechanisms (about which, see Leitner and Lessenich, 2003: 332), but also the outcomes that are produced by different welfare state arrangements, such as the number of claimants or the certainty with which people receive their benefits entitlements (about which, see Goodin et al., 1999: 38). From this scheme it follows that we may speak of four different connotations of solidarity that have reference to social security arrangements: (1) solidarity as individual motivation, (2) solidarity as individual action, (3) solidarity as a moral principle underlying welfare schemes and (4) solidarity as an institutionalised arrangement. Of course, the boundaries between the four conceptions are blurred and there may exist paradoxical interdependencies between them due, for example, to the fact that the more solidarity is institutionalised by collective welfare schemes, the more individual solidary sentiments may be undermined (van der Veen, 1998: 4).

Applying this classification, we can classify many welfare state studies with reference to the way the researchers use the concept of solidarity (Table 2).

TABLE 2. Classification of welfare state studies by the solidarity concepts used.

\begin{tabular}{|c|c|c|}
\hline & $\begin{array}{c}\text { Normative or affective } \\
\text { connotation }\end{array}$ & Factual conception \\
\hline Actors' dimension & $\begin{array}{l}\text { e.g. Taylor-Gooby (2001); } \\
\text { Ullrich (2002) }\end{array}$ & $\begin{array}{l}\text { e.g. Bergmark et al. (2000); } \\
\text { Ostner (2004) }\end{array}$ \\
\hline $\begin{array}{l}\text { Structural dimension } \\
\text { (institutionalised } \\
\text { dimension) }\end{array}$ & $\begin{array}{l}\text { e.g. Cox }(1998,2004) \text {; Clasen } \\
\text { and van Oorschot }(2002)\end{array}$ & $\begin{array}{l}\text { e.g. Veen (1998); Lessenich and } \\
\text { Leitner (2003) }\end{array}$ \\
\hline
\end{tabular}


The whole branch of literature dealing with public support for welfare state institutions (for example, Taylor-Gooby, 2001; Ullrich, 2002) can be classified under the category solidarity as individual motivation in the actors' dimension. Authors such as Bergmark et al. (2000) and Ostner (2004) are concerned with the actual solidaristic behaviour of individuals within groups and thus can be classified under the concept solidarity as individual action. Authors who understand solidarity as a moral principle underlying welfare schemes include Cox $(1998,2004)$ and Clasen and van Oorschot (2002). Studies dealing with the sub-dimensions of welfare institutions and their outcomes - for instance, van der Veen (1998) and Leitner and Lessenich (2003) - belong to the category of solidarity as institutionalised arrangement.

From this scheme it also becomes clear why welfare state restructuring should be assessed in terms of social solidarity. Although there are other principles by which social security institutions may be appraised - such as equality, reciprocity, need and universalism (about which, see Clasen and van Oorschot, 2002) - social solidarity is one of the most important with respect to the cohesion of society at all; social solidarity concerns not only normative connotations but also factual effects, and solidarity may refer not only to individuals but also to collectivities. In addition, social solidarity describes the very nature of a collective because solidarity - as we have learned from Durkheim and Weber - measures the degree of social integration and therefore 'represents the ties that unite individuals into a common moral community' (Bergmark et al., 2000: 239).

Collective agreements may be a source of solidarity (about which, see also van der Veen, 2005: 55-8). But what are the characteristics that enable a system of collective agreements on welfare to provide social solidarity? From Table 1 it becomes clear that the capacity of collective agreements to provide solidarity may be appraised with reference to all four connotations of solidarity. As there is not as yet any international comparative (survey) research on employers' or employees' individual support and feeling for collectively negotiated benefits, or on individual solidaristic behaviour connected to collectively negotiated benefits, I will focus below on the structural (institutionalised) dimension, concentrating on the factual understanding of solidarity; hence, I use the connotation of solidarity as an institutionalised arrangement.

In order to assess the solidaristic attributes of collective agreements on welfare, I suggest we focus on the following structural characteristics of collective agreements: (1) population coverage (for example, membership criteria) and level (for example, sectoral, intersectoral); (2) legal obligations and extension (based on the 'erga omnes' principle); (3) the level of benefits; and (4) the financing mechanism, hence the cost sharing between employers and employees and the question of whether the agreements are subsidised by taxation. ${ }^{6}$

All four dimensions also make clear the crucial differences between the degree of social solidarity that public insurance schemes may be able to 
provide and that collective agreements do. Compared with the nationwide, statecontrolled, compulsory social security institutions of the post-war welfare states, the solidarity that collective bargaining institutions provide is clearly limited.

The attributes of population coverage and level show these differences most clearly because nationwide, state-controlled, compulsory social security institutions and systems of welfare based on industrial agreements reflect different membership criteria. Within a system of collective agreements, the solidary group is no longer defined territorially but functionally (branch, intersectoral). Key actors in the provision of collectively negotiated benefits are no longer nationwide funds but trade unions and employers - collective actors that defend and promote their functionally defined industry-wide or intersectoral interests. In a system of collectively negotiated benefits, solidarity is redefined from being protective and redistributive solidarity - where the factual base of social cohesion is national and people support nationwide redistribution, which also shares risks between various regions and occupations - to being what Wolfgang Streeck (1999: 6-7) has called 'competitive and productive solidarity' - where the group to which social cohesion refers is the group of firms and employees covered by the collective agreement and where redistribution is only accepted if it takes into account the special needs of individual firms and employers engaged in the economic sector to which the collective agreement applies. Collective agreements will never reach the ideal type of social solidarity, namely basic security for all people: per definitionem collectively negotiated benefits are linked to the employees working under the collective agreement.

It is important to note that, although within a system of industrial agreements solidarity is defined functionally, this does not mean that the state retracts from the provision of social security. Governments may support collectively negotiated benefits by legislating on labour, tax and social policy law and by declaring the industrial agreements on social benefits generally binding (about which, see also van der Veen, 1998: 10). Collectively negotiated benefits - and, hence, collectively negotiated social solidarity - may be enforced to a greater or lesser extent by the state. As well as the state playing a decisive role in the emergence of nationwide compulsory social security institutions - hence, in the provision of territorially defined solidarity - its role may be crucial in the provision of functionally defined solidarity. However, unlike territorially defined solidarity within a system of functionally defined solidarity, risks are no longer shared by several branches or the entire working population; instead, risk sharing is now transferred to singular branches or even firms. This decrease in risk sharing means a decrease in collectively organised financial solidarity (about which, see also van der Veen, 1998: 9).

Public policies are also important for the second category that I have put forward to analyse the degree of solidarity which collectively negotiated social benefits may offer: the aspect of legal obligations and extension procedures. Also 
in relation to this category, the difference between nationwide, state-controlled, compulsory social security institutions and a system of industrial agreements of social security becomes clear. Whereas the membership of public insurance schemes is mostly mandatory for all employees, company membership of collectively negotiated welfare schemes may also be voluntary if no legal obligation exists or if collective agreements are not declared collectively binding; however, legislation may increase the circle of insured persons, and, hence, increase the extent of solidarity. As to the level of benefits, we can discern that in most cases collectively negotiated benefits may function as a top-up to public benefits and only provide a substitute for public benefits for high-wage earners. Finally, concerning the financial mechanism, we should note that, also in relation to this dimension, the extent of solidarity provided by collective agreements is limited, as collectively negotiated benefits will always be financed partially by employers and employees and never totally by taxes. Nevertheless, we will see that de facto tax subsidies on collectively negotiated benefits are widespread.

In what follows, I apply these conceptual accounts of social solidarity provided by industrial agreements to assess the extent of solidarity which the Danish, French, German and Dutch collective agreements may provide.

\section{Collectively negotiated benefits in Denmark, France, the Netherlands and Germany}

Table 3 sketches the development and extent of collectively negotiated benefits in the domains of occupational pensions, early retirement, and further training, and of state measures affecting tax, social security and labour law that support these agreements in Denmark, France, the Netherlands and Germany. It shows that in all four countries collective agreements have been concluded on welfare, and, nearly always, these schemes have been additionally supported by state measures.

To describe the collective agreements and to assess the extent of solidarity that these agreements may provide, I have arranged the table in such a way that the first row outlines the extension procedures (by declaring industrial agreements generally binding) in the four countries. The other rows characterise the industrial agreements on pension, early retirement and further education, alongside the dimensions 'Year of first agreement \& level \& coverage', 'Legal obligations/extension', the 'Level of benefits' and the 'Financial structure \& tax law/funding'.

The Netherlands has the most developed system of benefits based on industrial agreements. Germany has the worst developed system, with only marginal state funding, low coverage rates of collective agreements and agreements concluded in only a few sectors and then only recently. Whereas in Denmark, France and the Netherlands the use of the collective bargaining system 
TABLE 3. Collective agreements on pension, early retirement and further training in Denmark, France, Germany and the Netherlands.

\begin{tabular}{|c|c|c|c|c|}
\hline & Denmark & France & Germany & Netherlands \\
\hline $\begin{array}{l}\text { Extension (e.g. based } \\
\text { on the 'erga omnes' } \\
\text { principle); in general }\end{array}$ & $\begin{array}{l}\text { Yes, but voluntary, request of } \\
\text { social partners; law to be } \\
\text { enacted by the government; } \\
\text { no minimum requirements } \\
\text { for extension; 'absence of } \\
\text { extension' (Traxler, 1999: 75) }\end{array}$ & $\begin{array}{l}\text { Yes, almost automatic (ex } \\
\text { lege) but formal request } \\
\text { of Ministry of Labour or } \\
\text { social partners required; } \\
\text { extension is used for } \\
\text { industry-wide agreements } \\
\text { as well as for general multi- } \\
\text { industry agreements; 'perva- } \\
\text { sive extension practice' } \\
\text { (Traxler, 1994: 179) }\end{array}$ & $\begin{array}{l}\text { Yes, request of at least one } \\
\text { party to the collective } \\
\text { agreement; declaration by } \\
\text { the Ministry of Labour } \\
\text { and Social Affairs; } \\
\text { approval by a special } \\
\text { collective bargaining } \\
\text { committee (Tarifausschuss); } \\
\text { 'limited extension practice' } \\
\text { (Traxler, 1994: 179) }\end{array}$ & $\begin{array}{l}\text { Yes, request of one or more } \\
\text { bargaining partners; } \\
\text { decision of Ministry of } \\
\text { Social Affairs and } \\
\text { Employment; agreement } \\
\text { must cover 'sufficient } \\
\text { majority of relevant } \\
\text { employees'; 'limited } \\
\text { extension practice' } \\
\text { (Traxler, 1994: 179) }\end{array}$ \\
\hline Year \& Level \& Coverage & $\begin{array}{c}\text { Since } 1991 \text { (AMP); sectoral; } \\
90 \% \text { of employees }\end{array}$ & $\begin{array}{l}\text { Pension } \\
\text { Since 1947, 1961; inter } \\
\text { sectoral; as the system is } \\
\text { mandatory for all } \\
\text { employers and employees } \\
\text { the coverage rate is very } \\
\text { high }\end{array}$ & $\begin{array}{l}\text { Since 2001; sectoral; } \\
\text { metalworking pension } \\
\text { funds: } 160,000 \text { employees } \\
\text { and 9,000 companies } \\
\text { (May 2006); chemical } \\
\text { sector: more than } 400 \text { firms } \\
\text { with about 200,000 } \\
\text { employees (Dec. } 2003 \text { ) }\end{array}$ & $\begin{array}{l}\text { Since the first sectoral } \\
\text { collective agreement; } \\
\text { sectoral; large companies } \\
\text { have their own schemes } \\
91 \% \text { of employees }\end{array}$ \\
\hline $\begin{array}{l}\text { Legal Obligations/ } \\
\text { Extension }\end{array}$ & $\begin{array}{l}\text { No legal obligation; } \\
\text { no extension }\end{array}$ & $\begin{array}{l}1972 \text { act obliges employees } \\
\text { insured under public } \\
\text { pension insurance scheme } \\
\text { to participate in pension } \\
\text { systems based on } \\
\text { collective agreements; } \\
\text { extension through the } \\
1972 \text { act }\end{array}$ & $\begin{array}{l}\text { No obligation; however, a } \\
\text { collective agreement is } \\
\text { a precondition for } \\
\text { receiving governmental } \\
\text { support for } \\
\text { occupational pension } \\
\text { schemes; no extension }\end{array}$ & $\begin{array}{l}\text { Yes, } 1949 \text { act: mandating } \\
\text { following formal request } \\
\text { to the Minister of Social } \\
\text { Affairs by one of the } \\
\text { labour market partners; } \\
\text { opting out of mandating } \\
\text { is possible; extension } \\
\text { through the } 1949 \text { act }\end{array}$ \\
\hline
\end{tabular}


TABLE 3. Continued.

Financial structure \& Tax Law/Funding

Year \& Level \& Coverage

\section{Legal Obligations/} Extensions

Level of Benefits
Co-financed by employer/ employee; tax

exemptions on contributions (OECD 2005)

\section{Since 1979, efterlØn; since} mid-1990: part-time retirement; sectoral; very high; in 1999: 150,000 participants; part-time retirement: low participation rates (Hansen, 2002)

No obligation; no extension

Between $10 \%$ and $34 \%$ of fulltime income, depending on income level and the early retirement phase

(Hansen, 2000: 176, 179)

France

Germany

Netherlands social partners regularly adjust the scheme's operating parameters in order to balance income and expenditure

Co-financed by employer and employee; tax

exemptions on

contributions

\section{Early retiremen}

Since 1956 (UNICED); 1995; sectoral; widespread use of UNICED-financed early retirement

No obligation; generally binding

$50 \%$ of former full-time income and different top-ups

Between 70 and $85 \%$
Defined contribution scheme with a minimum benefit

Majority defined benefit scheme; defined

contribution scheme is increasing.

Mainly financed by employee, employers' contribution;

tax exemption on contributions

1996; sectoral; by the end of 2003, 854 collective agreements on part-time retirement were concluded, covering 16.3 million employees.

No obligation, the PartTime Retirement Act (Altersteilzeitgesetz) encourages part-time retirement, contingent, however, on a collective agreement between unions and employers; of former full-time income
Co-financed by employer and employee; tax contributions

Late 1970s; sectoral; In 2000 in $30 \%$ of the collective agreements (covering $20 \%$ of the employees) a provision for early retirement (VUT) was arranged;

No obligation; generally binding

\section{VUT: $70 \%$ of gross} salary exemption on 
Financial structure \& Tax Law/Funding

Year \& Level \& Coverage

\section{Legal Obligations/}

Extension

Level of Benefits

Financial structure

\& Tax Law/Funding
Co-financed by employer and employee

Public transfers

through transfers to

the unemployment funds

of trade unions

1977: AER; sectoral; 1 million out of

the total workforce of 2.9 million are entitled (Olesen, 1997)

No obligation;

no extension

Not available

Employer's contribution; funded through

the general taxation system; in 1997, the

total amount was

2,396 (DK, million),

also ESF funding
Co-financed by employer and employee

Public transfers through

transfers to UNICED

Further training

1970; intersectoral and sectoral; approx. 100

training funds exist

(Drexel, 2004)

Obligatory financial contribution by companies and the right to training in working hours; legal obligation to negotiate at branch level; extension through the obligatory financial contribution $50 \%$ of employee's net wage

Employer's contribution; additional funding of training based on a collective agreement by the state
Co-financed by employer and employee

Direct public payments, tax exemption on contributions

1983; sectoral; very low coverage

No obligation;

no extension

no specific law;
generally binding

deductions will

No obligation;
Co-financed by employer and employee; tax exemption on contributions; tax

be abolished in 2006

Late 1970s; sectoral; about $40 \%$ of Dutch enterprises are associated with one of the training and development $(\mathrm{O} \& \mathrm{O})$ funds

Not available

Co-financed by employer and employee

No state funding

Note: In Denmark and the Netherlands the collective funds for further training do also finance vocational education.

Source: Own compilation on the basis of www.eiro.eurofound.eu.int/index.html, www.cedefop.eu.int, www.world-pensions.org and secondary literature.

Not available

Co-financed by employer and employee; tax deductions (recently lowered); additional funding of $\mathrm{O} \& \mathrm{O}$ funds out of general tax revenue; $O \triangleleft O$-fondsen are also funded by ESF 
to provide and finance welfare has a long tradition, in Germany collectively negotiated benefits are a much more short-term phenomena.

In Denmark, France and the Netherlands the coverage of collective agreements on pension, early retirement (Denmark only: efterlØn) and further training is very high; in Germany it is not. In all countries, the level of pension benefits follows the defined contribution model; in the domain of early retirement, benefits are relatively high; in France, employees who take part in a measure of further training receive 50 per cent of their net wage. ${ }^{8}$ Regarding the funding and financial structure of the schemes, the benefits are mostly co-financed by employers' and employees' contributions. It is striking that tax exemptions are used as supportive and redistributive instruments in all four countries. ${ }^{9}$ The Danish system of further training is even funded mainly through general taxation. Often, special funds exist which are collectively managed by employers and trade unions in order to distribute and invest the money. ${ }^{10}$

From Table 3 it becomes clear that the role of the state in industrial relations is crucial for the extent of solidarity that collective agreements on social security are able to provide (about which, see also Trampusch, 2007). In countries where the state intervenes in collective bargaining by declaring collective agreements generally binding (with extension based on the 'erga omnes' principle) - countries like France and the Netherlands - there are legal requirements to reach collective agreements on welfare issues: with respect to pensions in both countries, with respect to training in France. In the Netherlands and France, the coverage rates of occupational pensions - regulated and financed through industrial agreements are much higher than in Denmark and Germany due to legal measures that make the systems obligatory for employers and employees. In Denmark and Germany, the principle of free collective bargaining permits state intervention in labour relations, and so collectively negotiated benefits have mainly developed on the basis of initiatives taken by trade unions and employers.

All in all, we can conclude that due to legal obligations and tax support, the extent of solidarity that industrial agreements provide is much higher in Denmark, France and the Netherlands than in Germany. Nevertheless, Table 3 offers merely a preliminary account of the extent of solidarity, as it does not analyse and measure the outcomes produced by the collectively negotiated benefits, such as the number of claimants, the certainty that people receive their benefits or the possible discriminating effects on women, low-paid employees and so on. These outcomes can only be analysed by case studies on the various agreements and surveys among the actors involved.

\section{Conclusion and prospects}

Despite major cutbacks in public welfare programmes there seems to be a tendency to integrate welfare issues in collective agreements. Theoretically as well 
as empirically, this article has offered an initial approach to the role collectively negotiated benefits may play in current welfare state restructuring. I argue that the evidence of collectively negotiated benefits contradicts the general view of a decreasing role for the social partners in the management of welfare. A scheme has been developed to distinguish between the different conceptions of solidarity used in the literature. This scheme has been applied to collectively negotiated benefits, suggesting we study solidarity provided by collective agreements as an institutionalised arrangement. Furthermore, I have argued that collective agreements on social benefits may compensate for losses in solidarity that are produced by the cutting of public welfare benefits. To 'measure' the degree of solidarity provided by industrial agreements I have suggested four dimensions: coverage, legal obligations and extension practices, level of benefits and financing mechanisms.

Within a system of collectively negotiated benefits, solidarity is limited compared with solidarity provided by nationwide, state-controlled, compulsory institutions of social security. Workers who are employed in prosperous, high-technology sectors are rewarded by better packages of wage and welfare compensation. Unskilled workers with a weaker bargaining position will be thrown back on need-based social assistance programmes (cf. Cox, 2004: 214). Collectively negotiated benefits may also reflect and reinforce inequalities in the workplace; they may disadvantage women and workers in atypical employment; they may give rise to distributional conflicts between insiders and outsiders of the labour market.

Hence, the disadvantage of welfare-based over collective agreements is that workers not employed under a collective agreement do not enjoy the benefits regulated in the agreement. The advantage to employees who work under a collective agreement on social benefits is that they receive more solidarity than in an individualistic, market-led private insurance scheme. This leads us to say that the self-regulative role of collective bargaining may change the direction of welfare development to a more solidarity-based solution rather than a full market-oriented system.

The evidence on collectively negotiated benefits points out that future research on welfare state restructuring should systematically collect evidence of collectively negotiated benefits, by comparing countries and by reviewing not only the domains of pensions, early retirement and further training, but also collective agreements on issues such as parental and maternity leave, unemployment insurance/active labour market policy, childcare and health care and sickness pay. In addition, the outcomes of collective agreements on social security have to be analysed: Do collectively negotiated benefits compensate for losses of income and solidarity caused by cuts in public welfare programmes? To what extent are declines in income and solidarity produced by welfare state retrenchment offset by collectively negotiated benefits? How can compensating effects be measured? 
Analytically and theoretically, the future studies should also take account the politics of interdependencies between public retrenchment policies and collectively negotiated benefits: Do governments use these schemes as a way to avoid blame for cuts in public benefits (about which, see Trampusch, 2006, 2007)? Do trade unions and employers regard them as a means to counterbalance cuts in public benefits and, in so doing, rearrange their political and economic activities in order to represent their social policy demands? Collectively negotiated benefits may be of interest to state actors, trade unions and employers (Ståhlberg, 2003: 190). However, the sustainability of collectively negotiated welfare schemes may also be constrained (and probably even lowered) by the general trend of the dismantling of centralised collective bargaining systems; small- and mediumsized firms may not be able to pay the costs of welfare benefits and, hence, be forced to opt out of collective agreements.

We also have to note that collectively negotiated benefits do not replace public schemes. In particular, the pension schemes in France and the Netherlands, which have a long tradition, have definitely been established as complementary schemes and not as substitutes. However, the existence of such complementary schemes now facilitates cuts in public schemes, as collectively negotiated schemes may function as 'retrenchment absorbers'. Hence, the emergence of collectively negotiated benefits is not a manifestation of retrenchment as such but, in all probability, a catalyst of it.

\section{Acknowledgements}

The author would like to thank Sigrid Leitner, Wim van Oorschot, Wolfgang Streeck, Kathleen Thelen and Romke van der Veen for their helpful comments on an earlier version of this article. I also thank the two anonymous reviewers of the journal for their helpful comments, and Tim Müller for his assistance in reviewing conceptions of solidarity. All remaining errors or opacities are the author's responsibility alone.

\section{Notes}

1 As regards industrial agreements on social security, the reports and comparative studies of EIRO are the most detailed source available. Although the data of EIRO are based on reports of single national correspondents, which may give rise to certain bias, this does not methodologically devalue them, as the national correspondents are experts on industrial relations in their countries. Furthermore, comparative EIRO reports are compiled on common questions posed to the correspondents.

2 Note, collective agreements also refer to other issues such as parental and maternity leave (Denmark, Netherlands), unemployment insurance/active labour market policy (France, Denmark, Netherlands), child care (Netherlands), health care and sickness pay (Netherlands) and the so-called 'life cycle oriented regulations' (levensloopregelingen) an integrated set of measures aimed at enabling workers to manage their working time and leave over their entire working lives in order to balance their work and family/care responsibilities - (Netherlands) (EIRO, 1998, 2001,2004a, 2004b, www.eiro. eurofound.eu.int). 
3 Note the fact that the solidarity-decline thesis is a moot question and in literature we find diverging claims and opinions on this thesis (for example, Gelissen, 2000). Van der Veen (2005: 50) suggests that solidarity may shift to lower levels (trade unions) or higher levels (the European Union). In addition, there are also various studies claiming that the solidarity-decline thesis lacks empirical evidence (Thorslund and Bergmark, 2000).

4 Leitner and Lessenich define solidarity as follows: 'Solidarity is a matter of altruistic, onesided transactions, of helping those incapable of helping themselves (and who, at the extreme, may never be able to give back and help others)' (2003: 329).

5 Hechter (1987: 17-19) contrasts two basic ways of constructing solidarity: on the one hand, solidarity refers to behaviour; on the other hand, to sentiments. Whereas factual solidarity is constructed 'by the proportion of private resources that each member [of a group] is expected to contribute to collectively determined means' (Hechter, 1987: 18) and can be measured by observable behaviour, affective solidarity is produced by sentiments that bind groups together (love, feeling of brotherhood).

6 Here I also use three of five sub-dimensions. Leitner and Lessenich (2003: 332) have suggested describing the degree and extent of solidarity provided by public insurance schemes. Leitner and Lessenich (2003: 332) distinguish between coverage, requirement, entitlement, level of benefit and financing mechanism.

7 For reasons of space, the article focuses on these three domains. However, collective agreements also refer to other issues (see note 2).

8 There is no English-speaking material available on the level of benefits in further training for the other countries.

9 However, recently in all four countries reforms have been carried out to reduce the tax exemptions in order to make early retirement schemes less attractive.

10 The Dutch employers and trade unions in particular have concluded collective agreements on the formation of sectoral funds (so-called CAO-fondsen) used to finance welfare benefits in labour market policy, child care, early retirement and further training. Both employers and employees pay contributions to these funds as part of the total wage (on which see Trampusch, 2006).

\section{References}

Alber, J. (2003), 'Recent developments in the German welfare state', in N. Gilbert and R. A. van Voorhis (eds), Changing Patterns of Social Protection: International Social Security Series, 9, New Brunswick: Transaction Publishers.

Arts, W. and Gelissen, J. (2001), 'Welfare states, solidarity and justice principles: does the type really matter?', Acta Sociologica, 44: 4, 283-99.

Bayertz, K. (1999), 'Four uses of "solidarity"', in K. Bayertz (ed.), Solidarity, Dordrecht: Kluwer.

Beckert, J., Eckert, J., Kohli, M. and Streeck, W. (2004), 'Einleitung', in J. Beckert, J. Eckert, M. Kohli and W. Streeck (eds), Transnationale Solidarität: Chancen und Grenzen, Frankfurt/Main, New York: Campus.

Béland, D. (2001), 'Does labor matter? Institutions, labor unions and pension reform in France and the United States', Journal of Public Policy, 21: 2, 153-72.

Berger, J. (2005), 'Einleitung', in J. Berger (ed.), Zerreißt das soziale Band?, Frankfurt/Main, New York: Campus.

Bergmark, Å., Thorslund, M. and Lindberg, E. (2000), 'Beyond benevolence - solidarity and welfare state transition in Sweden', International Journal of Social Welfare, 9: 4, 238-49.

Clark, G. L. (2003), European Pensions and Global Finance, Oxford: Oxford University Press.

Clasen, J. and Oorschot, W. van (2002), 'Changing principles in European social security', European Journal of Social Security, 4: 2, 89-112.

Cox, R. H. (1998), 'The consequences of welfare reform: how conceptions of social rights are changing', Journal of Social Policy, 27: 1, 1-16. 
Cox, R. H. (2004), 'The path-dependency of an idea: why Scandinavian welfare states remain distinct', Social Policy and Administration, 38: 2, 204-19.

Drexel, I. (2004), 'Frankreichs Fondssystem für Weiterbildung - Eine Alternative zu "Eigenverantwortung" und "Co-Investition", WSI Mitteilungen, 57: 4, 175-81.

Ebbinghaus, B. (2006), Reforming Early Retirement in Europe, Japan, and the USA, Oxford: Oxford University Press.

European Industrial Relations Observatory (EIRO) (1998), 'Collective bargaining and continuing vocational training in Europe', http://www.eiro.eurofound.eu.int/1998/04/ study/tn9804201s.html (1 May 2006).

European Industrial Relations Observatory (EIRO) (2001), 'Progressive retirement in Europe', http://www.eiro.eurofound.eu.int/2001/o9/study/tno109184s.html (1 May 2006).

European Industrial Relations Observatory (EIRO) (2004a), 'Family-related leave and industrial relations', http://www.eiro.eurofound.eu.int/2004/03/study/tno403101s.html (1 May 2006).

European Industrial Relations Observatory (EIRO) (2004b), 'Occupational pensions and industrial relations', http://www.eiro.eurofound.eu.int/2004/o4/study/tno404101s.html (1 May 2006).

Esping-Andersen, G. (1996), 'Conclusion: occupational welfare in the social policy nexus', in M. Shalev (ed.), The Privatization of Social Policy? Occupational Welfare and the Welfare State in America, Scandinavia and Japan, Houndsmill: Macmillan Press.

Gelissen, J. P.T.M. (2000), 'Popular support for institutionalised solidarity: a comparison between European welfare states', International Journal of Social Welfare, 9: 4, 285300.

Gilbert, N. (2004), Transformation of the Welfare State: The Silent Surrender of Public Responsibility, Oxford: Oxford University Press.

Gilbert, N. (2005), "The "enabling state"? From public to private responsibility for social protection: pathways and pitfall. Background note', http://www.oecd.org/dataoecd/ 61/38/34607114.pdf (1 May 2006).

Gilbert, N. and Voorhis, R. A. van (2003), 'Introduction: new configurations', in N. Gilbert and R. A. van Voorhis (eds), Changing Patterns of Social Protection. International Social Security Series, 9, New Brunswick/London: Transaction Publishers.

Goodin, R. E., Heady, B., Muffels, R. and Dirven, H.-J. (1999), The Real Worlds of Welfare Capitalism, Cambridge: Cambridge University Press.

Green-Pedersen, C. and Haverland, M. (2002), 'The new politics scholarship of the welfare state', Journal of European Social Policy, 12: 1, 43-51.

Greve, B. (2004), 'Denmark: universal or not so universal welfare state?', Social Policy and Adminstration, 38: 156-69.

Hacker, J. S. (2002), The Divided Welfare State: The Battle over Public and Private Social Benefits in the United States, Cambridge: Cambridge University Press.

Hansen, H. (2002), 'Active strategies for older workers in Denmark', in M. Jespen, D. Foden and M. Hutsbat (eds), Active Strategies for Older Workers in the European Union, Brussels: ETUI.

Hechter, M. (1987), Principles of Group Solidarity, Berkeley: University of California Press.

Hyde, M., Dixon, J. and Drover, G. (2003), 'Welfare state retrenchment or collective responsibility? The privatisation of public pensions in Western Europe', Social Policy and Society, 2: 3, 189-97.

Leitner, S. and Lessenich, S. (2003), 'Assessing welfare state change: the German social insurance state between reciprocity and solidarity', Journal of Public Policy, 23: 3, 325-47.

Lindbom, A. and Rothstein, B. (2004), 'The mysterious survival of the Swedish welfare state', Paper presented at the American Political Science Association, Panel 14-3 'The Survival of the Scandinavian Welfare State Model', 2-5 September, Chicago.

Lindenberg, S. (2002), 'Solidarity: its microfoundations and macrodependence: a framing approach', in P. Doreian and T. Fararo (eds), The Problem of Solidarity: Theories and Models, Amsterdam: Gordon \& Breach Publishers. 
Molina, O. and Rhodes, M. (2002), 'Corporatism: the past, present, and the future of a concept', Annual Review of Political Science, 5: 305-31.

OECD (2005), Pensions at a Glance: Public Policies across OECD Countries, Paris: OECD.

Olesen, K. (1997), 'Denmark: the role of social partners', http://www.ilo.org/public/english/ employment/skills/training/publ/denmark.htm (1 May 2006).

Oorschot, W. van (1998), 'From solidarity to selectivity: the reconstruction of the Dutch social security system 1980-2000', Social Policy Review, 10: 183-202.

Ostner, I. (2004), 'Familiale Solidarität', in J. Beckert, J. Eckert, M. Kohli and W. Streeck (eds), Transnationale Solidarität: Chancen und Grenzen, Frankfurt/Main, New York: Campus.

Pierson, P. (1994), Dismantling the Welfare State? Reagan, Thatcher, and the Politics of Retrenchment, Cambridge: Cambridge University Press.

Pierson, P. (1998), 'Irresistible forces, immovable objects: post-industrial welfare states confront permanent austerity', Journal of European Public Policy, 5: 4, 539-60.

Shalev, M. (1996), 'Introduction', in M. Shalev (ed.), The Privatization of Social Policy? Occupational Welfare and the Welfare State in America, Scandinavia and Japan, Houndsmill: Macmillan Press.

Ståhlberg, A.-C. (2003), 'Occupational welfare', in T. M. Anderson and P. Molander (eds), Alternatives for Welfare Policy: Coping with Internationalisation and Demographic Change, Cambridge: Cambridge University Press.

Streeck, W. (1999), 'Competitive solidarity: rethinking the "European social model”, MPIfG Working Paper, 1999/8, Max-Planck-Institut für Gesellschaftsforschung, Cologne.

Swaan, A. de (1988), In Care of the State, Cambridge: Polity Press.

Taylor-Gooby, P. (2001), 'Sustaining state welfare in hard times: who will foot the bill?', Journal of European Social Policy, 11: 2, 133-47.

Thorslund, M. and A. Bergmark (2000), 'Guest editorial - solidarity and welfare transition', International Journal of Social Welfare, 9: 4, 224-7.

Titmuss, R. M. (1976 [1958]), Essays on the Welfare State, London: Allen \& Unwin.

Trampusch, C. (2005), 'Institutional resettlement: the case of early retirement in Germany', in W. Streeck and K. Thelen (eds), Beyond Continuity: Institutional Change in Advanced Political Economies, Oxford: Oxford University Press.

Trampusch, C. (2006), 'Industrial relations and welfare states: the different dynamics of retrenchment in Germany and the Netherlands', European Journal of Social Policy, 16: 2, 121-33.

Trampusch, C. (2007), 'Industrial relations as a source of social policy: a typology of the institutional context for industrial agreements on social benefits', Social Policy and Administration, forthcoming.

Traxler, F. (1994), 'Collective bargaining: levels and coverage', in OECD Employment Outlook (July): 167-94.

Traxler, F. (1999), 'The state in industrial relations: a cross-national analysis of developments and socioeconomic effects', European Journal of Political Research, 36: 1, 55-85.

Ullrich, C. G. (2002), 'Reciprocity, justice and statutory health insurance in Germany', Journal of European Social Policy, 12: 2, 123-36.

Veen, R. Van Der (1998), 'Solidarity and social security: the consequences of the decollectivisation of the Dutch social security system', Tijdschrift sociale wetenschappen, 41: 3, 79-90.

Veen, R. Van Der (2005), Nieuwe vormen van solidariteit: Sociaal-democratische beginselen en de verzorgingsstaat, Amsterdam: Wiardi Beckman Stichting.

Veen, R. Van Der and Trommel, W. (1999), 'Managed liberalization of the Dutch welfare state: a review and analysis of the reform of the Dutch social security system, 1985-1998', Governance, 12: 3, 289-310. 